\title{
DEFORMED ICE AT THE BOTTOM OF ØSTERDALSISEN, NORWAY
}

\author{
By Wilfred H. Theakstone
}

(School of Geography, Victoria University of Manchester, Manchester, England)

DuRing studies carried out beneath the Norwegian glacier, Østerdalsisen (lat. $66^{\circ} 3^{\mathrm{I}^{\prime}} \mathrm{N}$., long. $14^{\circ} \mathrm{O}^{\prime}$ E.), between 1959 and 1964 , deformed ice has been noted frequently. At some places it is becoming detached from the glacier bottom, or has separated completely and is stagnating within subglacial caves. The tunnel-like caves, which extend as far as $80 \mathrm{~m}$. from the border of Østerdalsisen, are formed as the glacier slides over a series of rock steps. The glacier loses contact with the rock at the upper edge of each near-vertical cliff and curves down in an arch to the gently sloping "tread" below. It is at the down-stream end of such arches, where the glacier once again makes contact with its bed, that the ice is deformed; spirals form as a result of a clockwise rotation of the forward-moving ice. The rotation is caused by the oblique impact of the glacier bottom with the rock floor, and its clockwise nature reflects the relative orientations of the reversed slope of the floor and the direction of ice movement.

After making contact with the cave floor, the basal ice moves up the rock at an angle of ${ }^{20}-30^{\circ}$ to the line of greatest slope. The ice thus "trapped" against the floor deforms under the increased stress imposed upon it, and it is extruded in long "rolls" along the ice/rock contact as the glacier continues to move forward (Fig. I). In time, it is fractured (Fig. 2) or, as shearing occurs between it and the overlying ice, becomes detached from the glacier bottom. In some cases, the basal ice rotates through more than $90^{\circ}$ as it is dragged forward prior to separation (Fig. 3). Deformation is common at the down-stream end of arches overlain by about $30^{-}-50 \mathrm{~m}$. of ice.

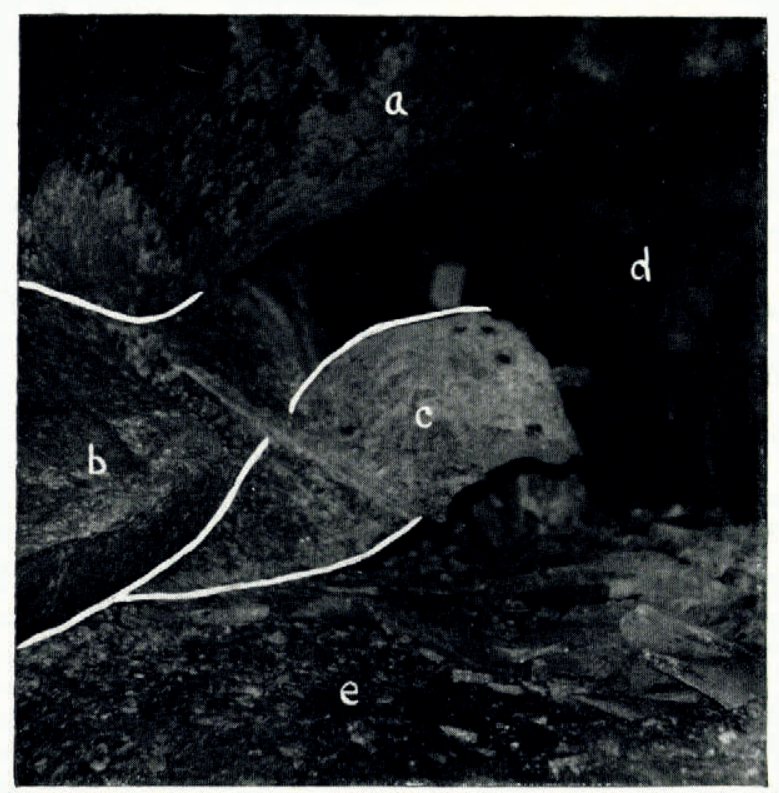

Fig. I. Deformed ice $(b)$ in the process of extrusion from the bottom of the glacier, 20 August 1961. The glacier (a), which loses contact with the rock as it flows over the cliff $(d)$, descends towards the floor $(e)$. The rock there is covered by ice formed by the freezing of snow melt water which enters the cave in spring from the valley side. Some of the ice from the floor $(c)$ has been picked up and dragged along by movement of the basal ice of the glacier to which it has frozen 


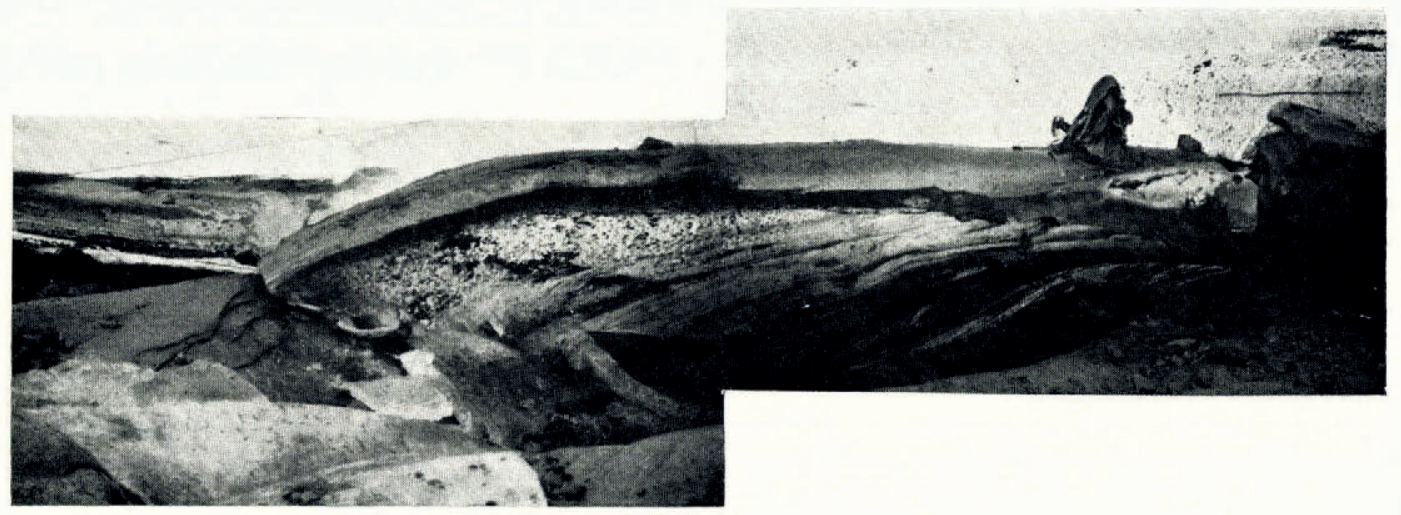

Fig. 2. Deformed and fractured basal ice, 30 July 1962. The glacier (top) flows from right to left, and the basal ice upon which the rucksack is standing is contorted and extruded sideways. Eventually, the spiralling ice is fractured (left), and thereafter becomes detached and stagnates within the cave. Note the reversed slope of the valley floor (left)

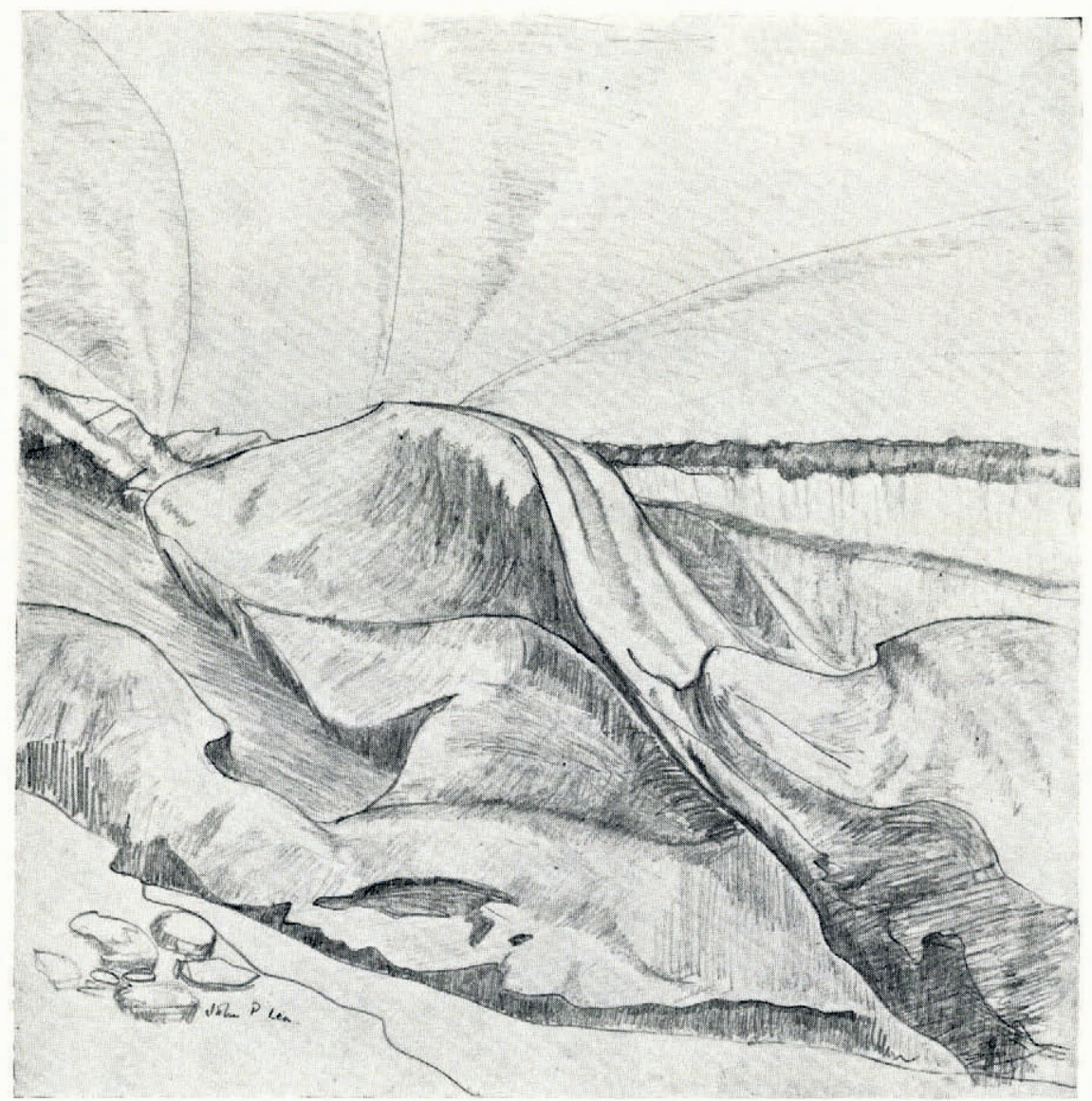

Fig. 3. Sketch of deformed and stagnating basal ice, ro August 196r. The spiralling basal ice has rotated through an angle of about $130^{\circ}$. Ice once in contact with the cave floor (right) has twisted so far as to face towards the roof (left) 
Carol (r 945) noted that ice within a cave below the Oberer Grindelwaldgletscher divided into two distinct layers and that, close to the down-stream contact with the rock floor, these moved with different velocities. The lower ice was less brittle and more cheese-like (käsig) than that above, and Carol believed that it was contorted against the upward-sloping floor because it became plastic under pressure. Photographs (Carol, 1947, fig. 6) suggest that the lowermost layer of ice was very similar to the deformed ice below Østerdalsisen, and that it had a similar origin, being squeezed out as the glacier bottom descended obliquely to the sloping rock floor. Kamb and LaChapelle ( 1964 ) reported plastic deformation over distances of $\mathrm{I} \mathrm{m}$. or more below Blue Glacier, Washington. At Østerdalsisen, as at Blue Glacier, there is no noticeable deformation of ice over distances much smaller than this.

MS. received 26 February 1965

\section{REFERENCES}

Carol, H. 1945. Beschreibung einer Gruppe von Gletscherrandklüften am Obern Grindelwaldgletscher. Mitteilungen der Geographisch-Ethnographischen Gesellschaft in Zürich, Bd. 42, 1943-45, p. 12-51.

Carol, H. 1947. The formation of roches moutonnées. Fournal of Glaciology, Vol. 1, No. 2, p. 57-59.

Kamb, [W.] B., and LaChapelle, E. [R.] I 964 . Direct observation of the mechanism of glacier sliding over bedrock. Journal of Glaciology, Vol. 5, No. 38, p. ${ }_{159-72 .}$ 